\title{
Unified Perspective for Categorization of Educational Quality Indicators from an Accreditation Process View - Relationships between Educational Quality Indicators Defined by Accrediting Agencies in México at the Institutional and Program Level, and Those Defined by Institutions of Higher Education
}

\author{
Jorge Sosa Lopez ${ }^{1}$, Miguel Alberto Salinas Yañez ${ }^{1}$, Maria Del Rocío Morales Salgado ${ }^{2} \&$ Maria De Lourdes Reyes \\ Vergara $^{2}$ \\ ${ }^{1}$ CETYS UNIVERSITY, Mexico \\ ${ }^{2}$ UPAEP, Mexico \\ Correspondence: Jorge Sosa Lopez, CETYS UNIVERSITY, Mexico
}

Received: February 29, 2016

Accepted: March 14, 2016

Online Published: March 21, 2016

doi:10.5430/ijhe.v5n2p113

URL: http://dx.doi.org/10.5430/ijhe.v5n2p113

\begin{abstract}
This research provides an introduction and background on accreditation of higher education in México focusing on FIMPES (Federation of Mexican Private Institutions of Higher Education), CACEI (Council for Accreditation and Certification of Education in Engineering), and CETYS University as a case study to establish relationships between educational quality indicators defined by these, with the purpose of defining a unified categorization model from the perspective of accreditation processes.
\end{abstract}

Keywords: Accreditation, Educational quality indicators, FIMPES, CACEI

\section{Introduction}

Institutions of higher education need to establish evaluation processes for accreditation, whose purpose is to revise their social function (pertinence), as well as the quality of the services they offer. It is in this context that the need arises for organizations that are in charge of accreditation processes with characteristics that provide credibility and reliability to the activities they perform.

Accreditation processes may be at the institutional level, where the evaluation is done in all areas of the educational institution, or at the program level, where the focus of the accreditation process is a particular area or program and its most relevant aspects (Baker, 2002).

Accreditation agencies define a set of indicators that the educational institution must comply with to obtain the seal of accreditation, which means that the institution has subjected itself to a peer review process by external entities that are tasked with validating the level of compliance that the institution demonstrates with regards to a set of defined standards of educational quality.

Accreditation processes both at the institutional and program level require that the educational institution establish a relationship between their own strategic educational quality indicators and those defined by the accreditation organizations, to be able to analyze and respond to the requirements of the accreditation process with evidence (information and documents).

In this article the research questions that are addressed are as follows:

- What are the educational quality indicators defined by accreditation agencies in México at the institutional and program levels?

- How do the educational quality indicators defined by accreditation agencies relate to those defined by an institution of higher education?

Therefore, the research objectives are: 
- $\quad$ To identify the educational quality indicators defined by accreditation agencies in México at the institutional and program levels.

- $\quad$ To describe the relationship between the educational quality indicators defined by accreditation agencies and those defined by an institution of higher education

The research hypotheses are:

- Accreditation agencies in México define a series of indicators that are similar, regardless of the profile or philosophy of the accreditation organization, or the level of accreditation (institutional or program).

- Educational quality indicator defined by accreditation agencies are related to each other and also with those defined by an institution of higher education, and may be grouped into a series of general categories.

The research is qualitative and exploratory (Hernandez, Fernández \& Baptista, 2010), based upon information from FIMPES (accreditation at the institutional level) and CACEI (accreditation for engineering at the program level), and CETYS University, a private non-for profit institution of higher education as a case study.

\section{Background}

Educational quality indicators are a set of elements that define standards for academic quality in an institution of higher education and they are the fundamental basis for any educational quality evaluation process.

The focus is on addressing the problem of organizing and having readily available the information required to support the administrative and decision making activities related to undertaking accreditation processes in an institution of higher education (Sánchez, Cantú, Rojas, Ortega \& Valenzuela, 2012).

Accreditation, in general terms is the acknowledgement that is awarded to academic units or specific programs after successful compliance of established criteria or standards of quality and has at its essential purpose to support decision making towards improvement, strengthening and reform within the institution of higher education.

Accreditation is a seal of collegiate quality, with the dual purpose of promoting and fostering improvement and quality assurance, and is based on self-regulation (Baker, 2002). Accreditation may be defined as the process by which an external entity awards "credibility" to the institution or its academic programs (Heitmann \& Augusti, 2001).

Accreditation may focus on inputs, processes or outputs, or a combination of these, and requires a series of procedures that require the gathering of evidence that allows for decision making with regards to the compliance of the institution or program with a series of established requirements, and the methods used to gather this information is usually common to those used in audits and evaluations done by external agents (Harvey, 2004).

Therefore, and institution that seeks accreditation will need to organize internally to undertake activities relating to gathering and organizing information and documents that serve the purpose of providing evidence for the different stages of the accreditation process: a) preparatory, b) self-study, c) site visit (Wood, 2006). In addition to the preparatory stages, there are stages relating to post-accreditation that have to do with follow-up on recommendations that also require gathering and organization of information as well as the deployment of continuous improvement processes.

Accreditation consists of many stages, each one demanding different requirements with regards to information and documents, as well as systems and structures for follow-up. According to the experience of the author, these stages may be defined as follows:

A. Eligibility: In this stage, the institution evaluates the requirements and criteria that are defined by the particular accreditation process, and prepares preliminary documentation based upon this evaluation, the purpose being to evaluate if the conditions are given to initiate and go through with the accreditation process. In this stage, the institution usually does a self-evaluation of its processes in contrast with the criteria established by the accreditation process, generates information, validates existing information and documents and identifies areas of opportunity. Ideally this self-evaluation should be done as a part of the institution's continuous improvement processes and not just with regards to accreditation requirements.

B. Reports: Once the eligibility stage is concluded, operational teams are deployed who are responsible for the analysis of a series of criteria defined by the accreditation process with the purpose of generating one or more reports that respond to the criteria in an integrated manner using evidence. In this stage a series of documents and information are identified as evidence that will serve to demonstrate compliance, as well as information tables and data according to the requirements defined in the accreditation process. 
C. Site Visit and Verification: The purpose of this stage is for the evaluating team defined by the accreditation agency, comprised of academic peers, to have a space in which they can visit the institution, verify and validate information and documents referred to in the report, conduct interviews. The information and documents from the report must be public and accessible to the evaluation team, and it is common that additional documents or information be required and made available for the evaluating team during the visit.

D. Resolution and Recommendations: Once the previous stages are concluded, results are generated and a resolution is provided by the accreditation agency, and this usually includes a series of recommendations which require follow-up and eventually derive in the generation of documents, policies and resources allotment by the institution.

The process is cyclic and is a part of an educational continuous improvement philosophy. The core is in the process itself and how it serves as a vehicle for necessary transformation for continuous improvement in the context of the institution (Zapata \& Tejeda, 2009). Furthermore, the documentation of processes and organization of information helps institutions operate in a more efficient manner (Brennan \& Austin, 2003).

Educational quality is one of the fundamental values of higher education, however it is not a simple task to identify, comprehend or homogenize the characteristic of educational quality, and define a series of educational quality indicators that may be measured and evaluated by all institutions of higher education regardless of accreditation process or their own differences in profile and philosophy (Baker, 2002).

The recognition of quality in an institution of higher education contemplates various areas such as academic programs, faculty, and infrastructure, to name a few (Barragan, 2009).

How then may we define educational quality? UNESCO establishes the following criteria:

- Efficiency of processes and their results, as well as the congruency and relevance of these with regards to social demands and expectations.

- It should be measured with regards to the achievement of goals and established goals for each institution due to the fact that this requires the efforts of an institutional community (academics, administrators, students, alumni, etc.) with a commitment to their social environment.

Therefore, educational quality in an institution of higher education is defined in congruency with its goals and objectives, involves all its members and is focused not only on capacity, but results as well, not only on quantitative aspects but also qualitative (Fernandez, 2003).

The topic of educational quality in higher education has taken more importance in the last decades, due to the focus on defining educational institutions as organizations with a responsibility to have accountability and respond to the expectations and needs of its various stakeholders, among these: society (Reddy, 2006).

Intrinsic quality forms a part of the nucleus of educational quality because of its focus on the processes of knowledge creation and learning in students; extrinsic quality has to do with the demands that society defines for higher education (Pereira, Lutz \& Hereens, 2002).

For the purposes of this research article, we define educational quality indicators as the set of elements that define standards of academic quality for an institution of higher education pertaining to its educational objectives, environment, stakeholders and institutional planning processes.

Educational quality indicators are the fundamental concept in this research because they are the basis for the evaluation processes of accreditation agencies as well as institutions of higher education, and they require the gathering and organization of information and documents that serve as evidence to demonstrate compliance with regards to institutional capacity and effectiveness.

\section{Institutional Accreditation of Higher Education in México}

In México there are organizations that seek the improvement of higher education via accreditation processes for educational quality; among these are the National Association of Universities and Institutions of Higher Education (ANUIES) and the Federation of Mexican Private Institutions of Higher Education (FIMPES).

ANUIES since its founding in 1950 has participated in the development of national programs, plans and policies, as well as the creation of organizations focused on the development of higher education in México. It is a non-governmental association comprised of 180 universities and institutions of higher education in México, both public and private.

FIMPES is comprised by a group of Mexican private institutions, and has as its purpose to improve communication 
and collaboration between its members and with other educational institutions in the country, respecting the particular goals of each, so that its members may better achieve their educational responsibilities. To be a member it is necessary to obtain an accreditation resolution that is awarded by an independent commission comprised of academics (FIMPES, 2014).

FIMPES members are a group of institutions that comply with a given profile defined by its accreditation process where there is participation of academic peers. FIMPES is the organization in México that is responsible for accrediting private universities.

Currently the membership and accreditation process is defined by the Membership and Permanence System Version III (FIMPES, 2014).

The accreditation status for a FIMPES member may fall into any of these categories:

a. Fully Accredited: The institution complies with at least $80 \%$ of the Capacity and Effectiveness criteria, as well as compliance with criteria 5.2

b. Accredited: The institution complies with at least $80 \%$ of the Capacity and Effectiveness criteria.

c. Conditionally Accredited: The institution complies with at least $75 \%$ of the Capacity and Effectiveness, but less than $80 \%$ of these.

d. Not-Accredited: The institution complies with less than $75 \%$ of the Capacity and Effectiveness criteria.

FIMPES has a list of 114 associated institutions of higher education of which 88 are accredited (77.1\%) and 26 are in the process of accreditation (22.9\%). Of the 88 that are accredited, 51 of these have the status of Fully Accredited $(57.9 \%)$.

Membership to FIMPES consists of the following two stages:

a. Integration of documentation: Includes a membership form, as well as institutional information and legal documentation.

b. Eligibility: The institution prepares a self-study in which it seeks to demonstrate that it has the means, processes, resources, and sufficient characteristic to submit itself to an evaluation process with high possibilities of success and therefore be considered as an aspiring member.

There are 11 Eligibility Requirements that all institutions must demonstrate evidence of compliance with:

1. Declaration of Principles and Mission.

2. Planning.

3. Normative reference.

4. Programs and educational services.

5. Admission policies.

6. Faculty (academic background, educational and professional experience).

7. Policies for academic work in concordance with the Mission.

8. Administrative personnel files.

9. Academic support services (library, electronic communication, information resources, didactic support, laboratories and workshops)

10. Facilities and infrastructure.

11. Economic and financial stability.

Once these requirements are satisfied and validated by the FIMPES Assembly, the institution is admitted to FIMPES as an Aspiring Member, and is committed to begin its formal self-study in a time frame of two years, following the guidelines established by the Accreditation through Institutional Development System (SADFI).

\subsection{Educational Quality Indicators Defined by FIMPES}

Accreditation in México has evolved from a prescriptive model focused mainly on capacity and merely quantitative evaluation of resources, to models based on educational effectiveness, with a quantitative as well as qualitative evaluation of resources as well as educational processes and results.

In this sense, the FIMPES SAFDI system considers two perspectives on the evaluation of the educational quality of 
an institution of higher education:

a. Institutional Capacity: Consists of demonstrating that the institution has the structures, normative references, processes and resources to achieve its Mission.

b. Institutional Effectiveness: Consists in demonstrating that the institution complies with its Mission and how productive it is in the achievement of its educational goals.

The educational quality indicators of FIMPES are evaluated using 39 criteria, of which 20 of these correspond to Institutional Capacity and 19 of these correspond to Institutional Effectiveness. The weight that the system awards to these criteria is: $40 \%$ Institutional Capacity and 60\% Institutional Effectiveness. The SAFDI system groups the criteria into ten categories, described in Table 1.

Table 1. Categories for SAFDI system criteria and their descriptions

\begin{tabular}{|c|c|}
\hline Category & Description \\
\hline $\begin{array}{l}\text { I. Institutional } \\
\text { Philosophy }\end{array}$ & $\begin{array}{l}\text { The institutional philosophy describes the stance and commitment that the institution has with regard to } \\
\text { the individual and to society. It includes the declaration of principles and is the framework of the } \\
\text { mission. At the same time, it determines the values that the institution promotes, in addition to its } \\
\text { educational purposes. }\end{array}$ \\
\hline II. Planning & $\begin{array}{l}\text { Planning implies that the institution has its future visualized, is committed to a process of improvement, } \\
\text { and can demonstrate how well it fulfills its mission and plans. It is conceived as a process that seeks to } \\
\text { successfully fulfill the institutional mission through the search for pertinent, accurate and timely } \\
\text { information to identify relevant issues and establish future actions to reach a certain vision; minimizing } \\
\text { weaknesses and nurturing the strengths of the institution; preventing risks and taking advantage of the } \\
\text { opportunities that exist in the environment. } \\
\text { It is an ongoing, cyclical and comprehensive process, and therefore covers educational as well as the } \\
\text { financial, physical and human resource areas of the institution. } \\
\text { Periodic evaluation of the achievements of the institution provides accurate information about the } \\
\text { performance of their mission and goals; this data is essential to make adjustments or continue moving } \\
\text { forward with the established planning. }\end{array}$ \\
\hline III. Policies & $\begin{array}{l}\text { Establishing an organizational structure, defining standards and the implementing an administrative } \\
\text { process are all important elements that contribute to the achievement of the institutional mission. } \\
\text { The regulatory framework ensures the university community and the general public that its processes } \\
\text { and activities are carried out according to clearly defined rules and standards. }\end{array}$ \\
\hline $\begin{array}{l}\text { IV. Academic } \\
\text { Programs }\end{array}$ & $\begin{array}{l}\text { Educational programs are the core of the operation of an institution of higher education; they allow it to } \\
\text { fulfill its basic functions (teaching, research and extension) and meet the needs of the community. } \\
\text { It is therefore necessary to establish criteria relative to the congruence between the institutional mission } \\
\text { and the goals of the programs it offers. }\end{array}$ \\
\hline V. Faculty & $\begin{array}{l}\text { One of the elements that have a major impact on learning outcomes is the quality of the faculty. } \\
\text { Therefore selection, development and retention of competent faculty for all academic levels is of the } \\
\text { utmost importance to achieving high educational standards in the institution's programs. In addition, the } \\
\text { commitment of the faculty with institutional goals will determine, in a large measure to Institutional and } \\
\text { Academic Program Effectiveness. }\end{array}$ \\
\hline VI. Students & $\begin{array}{l}\text { The student is the main protagonist in the processes and activities that take place daily in institutions of } \\
\text { higher education. } \\
\text { The institutions that consider the student as the immediate beneficiary of the education they provide are } \\
\text { those that have aligned their mission and educational objectives with their core processes, from } \\
\text { promotion and admissions, to degree requirements alumni follow-up. }\end{array}$ \\
\hline $\begin{array}{l}\text { VII. } \\
\text { Administrative } \\
\text { Personnel }\end{array}$ & $\begin{array}{l}\text { Administrative personnel are those who work in institutional, academic and administrative support } \\
\text { areas. It also includes technical and service staff. } \\
\text { Administrative personnel play a very important role in the successful achievement of the mission of an } \\
\text { institution. It is therefore important to carefully consider the conditions, criteria and for selection, } \\
\text { recruiting, hiring, induction, development, evaluation and promotion. }\end{array}$ \\
\hline
\end{tabular}




\begin{tabular}{|c|c|}
\hline $\begin{array}{l}\text { VIII. } \\
\text { Academic } \\
\text { Support }\end{array}$ & $\begin{array}{l}\text { Academic support consists of all the elements that are put at the disposal of students, faculty and staff, to } \\
\text { facilitate the academic activities of the institution. They are indispensable for the successful } \\
\text { accomplishment of the mission and institutional goals. } \\
\text { It is important that the institution provide its students and faculty the necessary resources for the } \\
\text { achievement of student learning to reach institutional effectiveness. } \\
\text { Such resources include libraries and information centers; laboratories and workshops; information and } \\
\text { communication technologies; educational resources and support. }\end{array}$ \\
\hline $\begin{array}{l}\text { IX. Physical } \\
\text { Resources }\end{array}$ & $\begin{array}{l}\text { The physical resources determine the type of educational process performed in them. Therefore, it is } \\
\text { important for the educational community to determine what the needs are in this regard. Successful } \\
\text { fulfillment of the objectives of the institution depends, in part, of its physical resources; to do this, they } \\
\text { need to be developed based upon the planning process, and be kept in proper operating conditions } \\
\text { through planning and well-established criteria. }\end{array}$ \\
\hline & $\begin{array}{l}\text { Such resources include buildings, parking lots, equipment, laboratories, workshops and materials. It is } \\
\text { important that these are arranged in terms of quality, safety, health and environmental protection. }\end{array}$ \\
\hline $\begin{array}{l}\text { X. Financial } \\
\text { Resources }\end{array}$ & $\begin{array}{l}\text { Funding allows the university community to seek institutional effectiveness, within a framework of } \\
\text { security and continuity; therefore, sound finances are essential for mission accomplishment. }\end{array}$ \\
\hline
\end{tabular}

This new focus on accreditation in México not only evaluates if the institution has defined and implemented elements related to capacity, but also to what level the institution is complying with what it defines in its mission, in other words a focus not only on inputs and structures, but on results.

\section{Academic Program Accreditation in México}

Program accreditation for an institution of higher education is the public acknowledgement awarded by a non-governmental accrediting agency, stating that an academic program complies with a series of principles, criteria, indicators and standards of quality in its structure, as well as organization, operation, inputs, teaching and learning processes, services and results. In México, accrediting agencies for academic programs must be formally recognized by the Higher Education Academic Program Accreditation Council, or COPAES (COPAES, 2014).

Accreditation of an academic program also means that the program has social pertinence. The mechanisms used to assure quality in education are diagnostic evaluation and accreditation. Accreditation done by agencies recognized by COPAES is a result of a process whose objective is to publically and formally recognize that there is compliance with criteria for quality, fostering continuous improvement by way of the recommendations that are issued. Accreditation is for a determined period of time, after which the academic programs are re-evaluated considering the issued recommendation (CACEI, 2014).

The Council for Accreditation and Certification of Education in Engineering (CACEI) is the agency in México that accredits engineering programs and is recognized by COPAES.

The accreditation process is voluntary and takes into account internationally accepted criteria defined by similar agencies, as well as those defined by COPAES.

Accreditation is done by active participation of peer evaluators from the academic and public sectors. The decisions on the academic quality of evaluated programs are collegiate and seek, with the information that is provided to institutions, to support decision making relating to improvement, providing objective and pertinent elements that lead to improvement plans with defined objectives, goals, strategies and programming that aid in the responding to recommendations, and therefore contributing to the continuous improvement of the academic program (CACEI Reference Framework, 2014). 


\subsection{Educational Quality Indicators Defined by CACEI}

CACEI defines 10 categories of analysis that group indicators that have common characteristics, shown in Table 2 .

Table 2. Categories of analysis defined by CACEI

\begin{tabular}{|c|c|c|}
\hline \# & Categories & Indicators \\
\hline 1 & Faculty & $\begin{array}{l}\text { Recruitment, selection, hiring, development, categorization and degrees, } \\
\text { workload, evaluation and promotion. }\end{array}$ \\
\hline 2 & Students & $\begin{array}{l}\text { Selection, enrollment, degree obtainment requirements, attrition, } \\
\text { retention. }\end{array}$ \\
\hline 3 & Academic Programs & $\begin{array}{l}\text { Educational objectives, courses, content, curricular flexibility, program } \\
\text { review and evaluation }\end{array}$ \\
\hline 4 & Evaluation of Learning & Methodology, pedagogy, scholarship. \\
\hline 5 & Integral Education & $\begin{array}{l}\text { Entrepreneurship, cultural and sports activities, professional guidance, } \\
\text { healthy lifestyle and values. }\end{array}$ \\
\hline 6 & Learning Support Services & Tutoring, library, student support services on Campus. \\
\hline 7 & Linkage - Extension & $\begin{array}{l}\text { Linkage with private and social sectors, alumni follow-up, student } \\
\text { exchange, social service, extension, job seeking. }\end{array}$ \\
\hline 8 & $\begin{array}{l}\text { Research and Technological } \\
\text { Development }\end{array}$ & $\begin{array}{l}\text { Research lines and projects, resources for research and promotion of } \\
\text { research activities, research impact. }\end{array}$ \\
\hline 9 & Infrastructure \& Equipment & $\begin{array}{l}\text { Infrastructure, laboratories, information technologies, specialized } \\
\text { equipment for academia and research }\end{array}$ \\
\hline 10 & Administration and Finances & $\begin{array}{l}\text { Institutional planning and evaluation, administrative support services, } \\
\text { financial resource planning. }\end{array}$ \\
\hline
\end{tabular}

Indicators are grouped into two general requirement categories: minimum and complimentary. Minimum requirement indicators are those that are mandatory for compliance with the elements that CACEI requires for a program of quality. Complimentary requirement indicators are those that are desirable and provide added value to the program.

For CACEI, the indicators describe quantitative and qualitative elements that describe the program, and these are analyzed according to previously established criteria that define the quality of an academic program in engineering.

\section{Relationships between Educational Quality Indicators Defined by FIMPES \& CACEI}

Even though each accrediting agency has different profiles (FIMPES for institutional accreditation and CACEI for accreditation of academic programs in engineering), relationships can be established between the indicators that each define, an also these may be grouped. Using FIMPES as a reference, relationships are established with CACEI based upon groups with similar characteristics, with the following findings:

- FIMPES gives more importance to Institutional Philosophy from the institutional accreditation perspective than CACEI from the academic program perspective. However, the indicators defined by CACEI for Policies can be related with those defined by FIMPES and be placed in the same grouping.

- There is congruence between indicators relating to Faculty defined by FIMPES with those defined by CACEI, where aspects relating to selection, recruitment, evaluation, categorization/academic degrees are stand outs.

- There is also congruence between indicators relating to Students defined by FIMPES with those defined by CACEI, where aspects relating to enrollment, selection, policies and follow-up are stand outs.

- $\quad$ There are common elements with regards to Academic Programs defined by both FIMPES and CACEI, such as entry requirements, educational objectives and learning outcomes, curricular and co-curricular components and evaluation. 
- In both cases, research is defined as it relates to the profile of the institution, based upon what the institution defines as its research areas and projects, their definition and impact. In the case of FIMPES, educational and institutional research for continuous improvement is also considered.

- In both cases the focus on physical resources is centered on the infrastructure and equipment required to support academic programs and their development. Also, programs that are related to health and security fall into this grouping.

- In the case of FIMPES, the indicators for this category are defined in greater detail than in the case of CACEI, which takes a more general approach and with a focus on the particular requirements of the academic program.

- In this case, as well, the focus of FIMPES is more detailed than CACEI, whose focus is more on the particular requirements of the academic program.

Tables 3 and 4 provide two examples of the analysis that was done to establish relationships for the categories of Faculty and Research.

Table 3. Relationships for the Faculty category

\section{FIMPES}

NOTE: "C" indicates Capacity criteria and " $E$ " indicates

\section{Effectiveness criteria}

5.2 The Institution shall hire competent and qualified faculty to achieve its mission and its institutional goals. It shall demonstrate that at least $33 \%$ of the course hours shall be taught by faculty with academic degrees above the level at which they teach. In the case of doctoral studies, $100 \%$ of faculty shall have doctoral degrees $(\mathrm{C})$.

5.4 The institution shall demonstrate that it provides faculty with opportunities to continue their personal growth as well as academic and professional development; and that these opportunities are aligned with its mission $(\mathrm{C})$.

5.5 The institution shall demonstrate faculty participation in institutional activities through various structures such as committees, academies and work teams; which shall be aligned with the institutional mission and shall operate under a framework of policies determined by the governing body $(\mathrm{C})$.

5.1 The Institution shall demonstrate that it has an adequate number of fulltime faculty to support its mission and ensure the quality and integrity of its academic programs (E).

5.3 The institution shall demonstrate the existence and implementation of procedures to periodically assess the performance of each faculty member, and those assessments shall be used to improve institutional effectiveness (E).

5.6 The institution shall demonstrate that it has rules and procedures to regulate the work of faculty that is consistent and congruent with the institutional mission. (E).

\section{CACEI}

NOTE: "M" indicates a Minimum criteria and " $C$ " indicates a

Complimentary criteria

\subsection{Selection (M).}

1.5 Categorization and degrees $(\mathrm{M})$.

\subsection{Recruitment (C).}

1.3 Hiring $(\mathrm{C})$.

1.4 Faculty development (M).

1.6 Faculty workload (C).

1.2 Selection $(\mathrm{M})$.

1.5 Categorization and degrees $(\mathrm{M})$.

1.1 Recruitment (C).

1.3 Hiring $(\mathrm{C})$.

1.7 Evaluation $(\mathrm{M})$.

1.8 Promotion $(\mathrm{C})$.

1.6 Faculty workload (C). 
Table 4. Relationships for the Research category

\begin{tabular}{lll} 
FIMPES & CACEI \\
NOTE: "C" indicates Capacity criteria and "E" indicates & NOTE: "M" indicates a Minimum criteria and \\
Effectiveness criteria & "C" indicates a Complimentary criteria \\
\hline
\end{tabular}

4.3 The institution shall develop research activities; it shall

8.1 Research lines and projects $(\mathrm{M})$.

develop and implement a Research Plan aligned with its

8.2 Support resources for research $(\mathrm{C})$.

institutional philosophy that is consistent and congruent with its

academic offering; and demonstrate the impact of its research

activities.

The development of scientific research programs: basic and

applied, is mandatory for institutions offering Masters programs

of MI1, MI2 and MI3 type; and for all that offer doctorates of DI1,

DI2 and DI3 type, designed to develop researchers (E).

4.4 The institution shall demonstrate that it has educational and

8.1 Research lines and projects (M).

institutional research programs. There shall also be programs for

the development of research skills in the students $(\mathrm{E})$.

4.5 The institution shall demonstrate that it uses the results

8.3 Promotion of research $(\mathrm{C})$.

obtained from educational research for the continuous

8.4 Research impact (C).

improvement of its academic programs (E).

\section{Educational Quality Indicators for an Institution of Higher Education Accredited by FIMPES and CETYS University Case Study}

An analysis was done based upon institution of higher education accredited by FIMPEs, and with a focus on CETYS University, a private non-for-profit university member of FIMPES with three campuses located in the northwestern region of México, in Baja California.

The information that was gathered came from the following sources:

A. Review of public information of institutions of higher education accredited by FIMPES.

B. Interviews conducted at CETYS University.

C. Review of the CETYS University Strategic Plan for 2020.

6.1 Review of Public Information of Institutions of Higher Education Accredited by FIMPES

A review of public information was done for the 51 institutions associated with FIMPES that have the "Full Accreditation" status, focusing on promotional aspects as well as their institutional philosophy (mission, vision and educational model), with the purpose of identifying elements that would be considered as educational quality indicators for each institution.

The results are presented in Figure 1 which shows the indicators that were identified and their corresponding frequency. There are many common elements identified in these institutions, regardless of the profile of the institution, and these are mostly related to faculty, academic programs and students among others. 


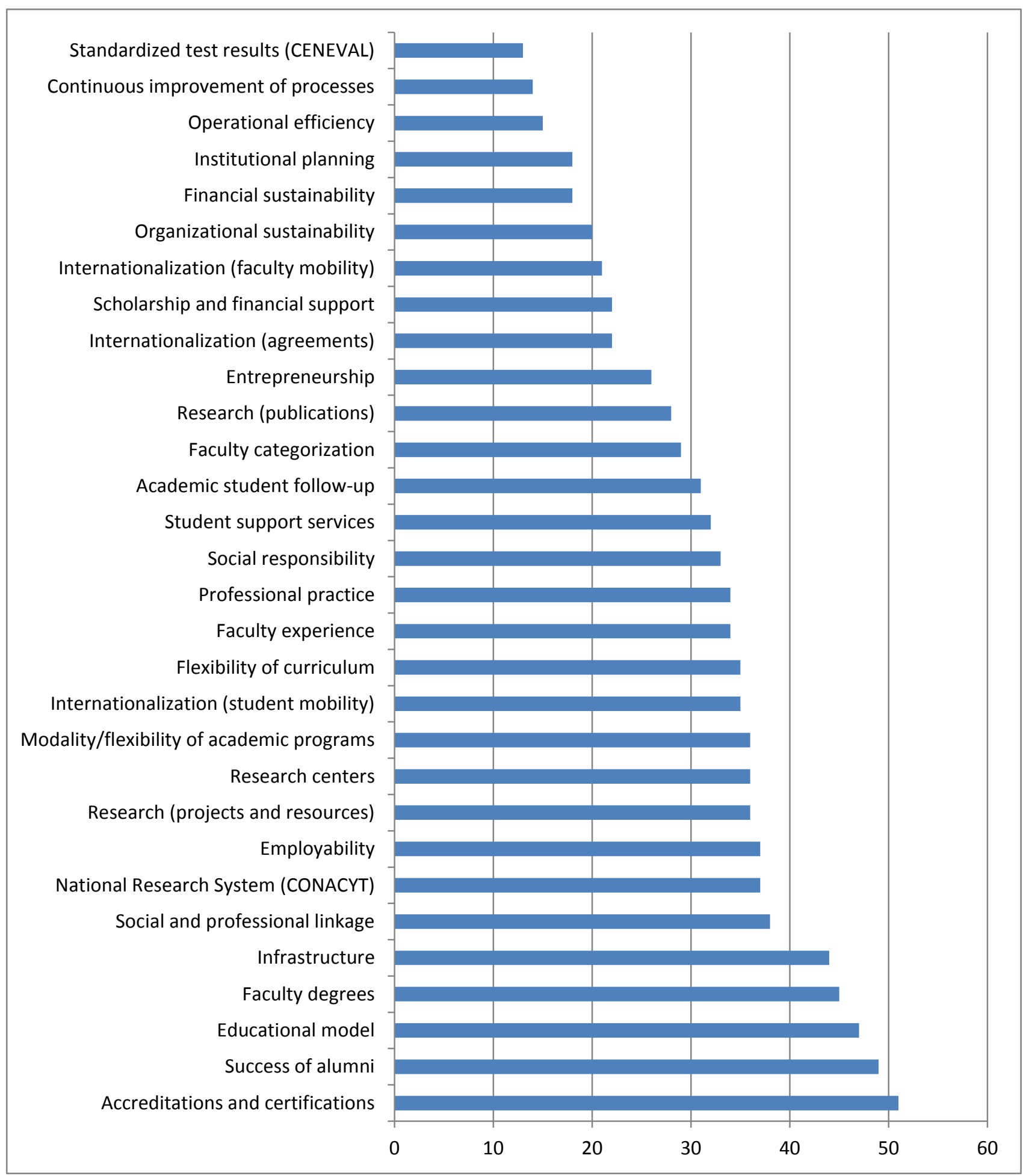

Figure 1. Educational quality indicators identified for higher education institutions accredited by FIMPES and their corresponding frequency 


\subsection{Interviews}

A total of 33 interviews were conducted in the three campuses of CETYS University. Table 5 shows the distribution of the different personnel that was interviewed.

A wide range of personnel were considered from different levels, as well as the various academic areas and colleges with the purpose of having a diverse perspective from within the institution. The criteria for the selection of the group to be interviewed were the following:

1. The group should represent the academic perspective of the institution.

2. The group should represent personnel from the three campuses.

3. The group should be representative of the various academic programs and colleges.

4. The group should represent personnel from all levels of the institution, beginning from the president all the way to faculty.

All personnel were invited to participate via an e-mail that explained the research objective. The interviews were conducted personally or via e-mail depending on the availability of the person in question. The interviewers were asked to indicate 6 educational quality indicators for CETYS University and explain their importance, pertinence and relevance to the institution. All personnel indicated in Table 5 agreed to participate and their answers were to be kept anonymous.

Table 5. Distribution of personnel that were interviewed in CETYS University

\begin{tabular}{|c|c|c|c|c|c|}
\hline \multirow{2}{*}{ Personnel category } & \multirow{2}{*}{ Institutional } & \multicolumn{3}{|c|}{ Campus } & \multirow{2}{*}{ TOTAL } \\
\hline & & Mexicali & Tijuana & Ensenada & \\
\hline President & 1 & & & & 1 \\
\hline Former President & 1 & & & & 1 \\
\hline Vice-President of Academic Affairs & 1 & & & & 1 \\
\hline Vice-President of Operations & 1 & & & & 1 \\
\hline College Director & 3 & & & & 3 \\
\hline Academic Director & 1 & & & & 1 \\
\hline President's Staff & 2 & & & & 2 \\
\hline Campus Directors & & 1 & 1 & 1 & 3 \\
\hline Academic Deans & & 1 & 1 & 1 & 3 \\
\hline School Dean & & 4 & 1 & 2 & 7 \\
\hline Academic Program Coordinator & & 9 & 1 & & 10 \\
\hline TOTAL & 10 & 15 & 4 & 4 & 33 \\
\hline
\end{tabular}

The results are presented in Figure 2 which shows the indicators that were identified and their corresponding frequency. The results show a diverse panorama on the topic of educational quality indicators from the perspective of the CETYS University personnel that were interviewed, who are immersed in the educational process within the institution and share the institutional vision for development. Among these elements there are those that may be considered as fundamental for institutions of higher education in general (such as faculty, academic programs and students), and there are also elements that may be considered as particular or differentiating components of education at CETYS, such as internationalization and accreditation. 


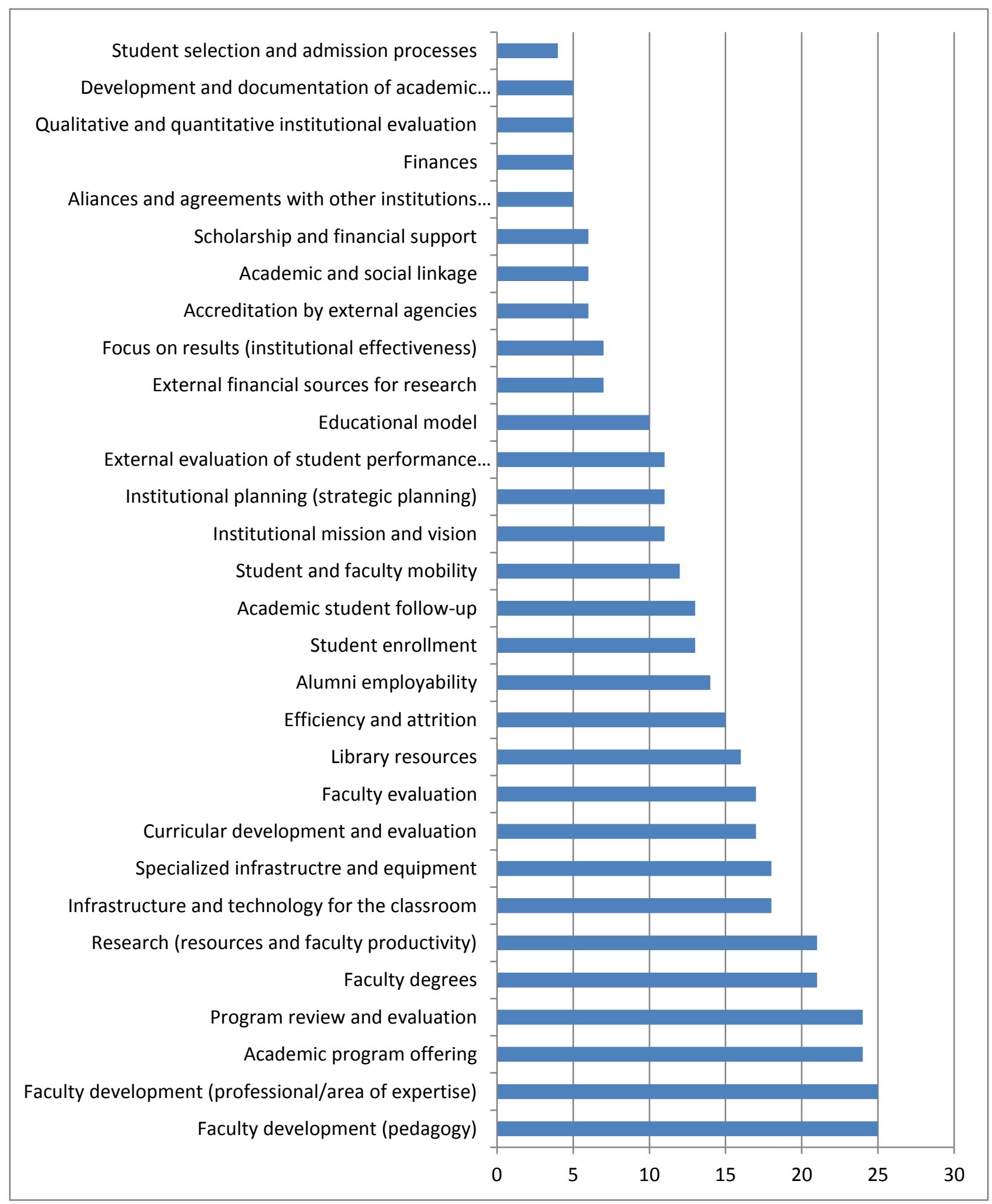

Figure 2. Educational quality indicators identified by CETYS University personnel and their corresponding frequency 


\subsection{CETYS Strategic Plan for 2020}

CETYS University defines 10 year planning cycles, the most recent being in done in 2010 where the 10 year planning was done towards 2020, and this plan is called the CETYS 2020 Strategic Plan.

The CETYS Vision for 2020 states that it will be an institution with high educational quality, globally competitive, operating in learning communities and recognized by its actions and results in favor of sustainable development.

CETYS University defines a reference frame to measure institutional effectiveness with a series of indicators that will be evaluated as part of the continuous improvement cycle of the Strategic Plan for 2020. The indicators are distributed into 5 categories, described in Table 6.

Table 6. Categories and indicators for educational quality as defined in the CETYS Strategic Plan for 2020

\begin{tabular}{|c|c|c|}
\hline Category & Description & Indicators \\
\hline \multirow{9}{*}{ 1. Students } & \multirow{9}{*}{$\begin{array}{l}\text { This component is comprised of } \\
\text { indicators relating to prospective } \\
\text { students, enrolled students and } \\
\text { alumni, and seeks to answer the } \\
\text { questions: Is the institution } \\
\text { reaching out and serving its } \\
\text { targeted market and student } \\
\text { population? }\end{array}$} & 1.1 Admission test scores \\
\hline & & 1.2 Student population \\
\hline & & 1.3 Retention \\
\hline & & 1.4 Efficiency and attrition \\
\hline & & 1.5 Standardized test results (EGEL). \\
\hline & & 1.6 Institutional learning outcomes. \\
\hline & & 1.7 Academic program learning outcomes \\
\hline & & 1.8 Co-curriculum \\
\hline & & 1.9 Satisfaction with regards to services \\
\hline \multirow{5}{*}{ 2. Faculty } & \multirow{5}{*}{$\begin{array}{l}\text { This component focuses on } \\
\text { faculty productivity and } \\
\text { instruction costs. Faculty } \\
\text { productivity is focused strongly } \\
\text { on the achievement of student } \\
\text { learning outcomes and } \\
\text { educational objectives as well as } \\
\text { research. }\end{array}$} & 2.1 Curricular coverage in hours \\
\hline & & 2.2 Doctoral studies \\
\hline & & 2.3 Faculty performance \\
\hline & & 2.4 Research productivity \\
\hline & & $\begin{array}{l}2.5 \text { Research and linkage projects (via the Centers of } \\
\text { Excellence). }\end{array}$ \\
\hline \multirow{2}{*}{ 3. Alumni } & \multirow{2}{*}{$\begin{array}{l}\text { The metrics in this component are } \\
\text { focused on alumni performance, } \\
\text { reflected on their employability } \\
\text { and the value awarded to our } \\
\text { alumni by employers. }\end{array}$} & $\begin{array}{l}\text { 3.1 Employment after one year of completion of } \\
\text { academic program }\end{array}$ \\
\hline & & $\begin{array}{l}3.2 \text { Professional performance as evaluated by } \\
\text { employers }\end{array}$ \\
\hline \multirow{6}{*}{ 4. Programs } & \multirow{6}{*}{$\begin{array}{l}\text { This component focuses on } \\
\text { academic program accreditation } \\
\text { in México (CACEI, CACECA, } \\
\text { etc.) as well as international } \\
\text { accreditation (ABET; ACBSP, } \\
\text { etc.), without losing sight of the } \\
\text { quality, pertinence and flexibility } \\
\text { of the academic offering. }\end{array}$} & 4.1 National program accreditation \\
\hline & & 4.2 International program accreditation \\
\hline & & 4.3 Program review and evaluation \\
\hline & & $\begin{array}{l}4.4 \text { New academic program in congruence with } \\
\text { regional development }\end{array}$ \\
\hline & & $\begin{array}{l}\text { 4.5 Integration of differentiating elements such as } \\
\text { entrepreneurship, internationalization and } \\
\text { sustainability }\end{array}$ \\
\hline & & $\begin{array}{l}\text { 4.6 Diversification of academic offering (dual } \\
\text { degrees, on-line programs, certificates, etc.) }\end{array}$ \\
\hline \multirow{5}{*}{$\begin{array}{l}\text { 5. Administration } \\
\text { and Finances }\end{array}$} & \multirow{5}{*}{$\begin{array}{l}\text { The metrics for this component } \\
\text { focus on financial health of the } \\
\text { institution (operational results, } \\
\text { external funding), donation, } \\
\text { scholarships and other financial } \\
\text { support. }\end{array}$} & 5.1 Operational results \\
\hline & & 5.2 External funding sources \\
\hline & & 5.3 Fundraising campaign \\
\hline & & 5.4 Alumni donors \\
\hline & & 5.5 Scholarships \\
\hline
\end{tabular}




\section{Identifying Educational Quality Indicators}

The quality indicators identified from the review of institutions associated to FIMPES and the CETYS surveys were grouped into categories in a similar manner to the previous grouping made with the FIMPES and CACEI indicators, with the following findings:

- Common elements to indicators relating to Institutional Philosophy are related to accreditation and certification, which is congruent with institutions that seek accreditation from external agencies. Also, aspects pertaining to internationalization (mobility, agreements, etc.) and linkage (social and professional) stand out.

- Common elements to indicators relating to Faculty are academic degrees, development and evaluation, as well as internationalization.

- Common elements to indicators relating to Students are enrollment, standardized testing (CENEVAL) and internationalization.

- Common elements to indicators relating to Academic Programs are educational offering and alumni follow-up. Also, aspects relating to differentiating elements of the academic programs stand out, such as linkage, internships, modality/flexibility. Program accreditation is also a common element as well as academic program review.

- With regards to indicators relating to Research, Institutions associated with FIMPES are focused on SNI (National Research System of CONACYT), and the common elements with CETYS are related with resources to support research with a particular focus on financing.

- Common elements to indicators relating to Physical Resources are resources for support of education as well as laboratories, specialized equipment and libraries/information centers.

- With regards to indicators relating to Academic and Administrative Support, there are common elements for all indicators, in particular those that have to do with follow-up and academic support for students, which is congruent with retention efforts. Financial support is also a stand out, and this is congruent for a group of institutions that are private where tuition is an important factor.

- With regards to indicators relating to Planning and Finances, common elements are related to institutional planning, continuous improvement as well as financial stability/health.

\section{Relationships between Educational Quality Indicators Defined by CETYS University, FIMPES and CACEI}

Table 7 identifies the relationships between educational quality indicators defined by CACEI and FIMPES, with those defined by CETYS University in its development plan for 2020.

There are relationships between many indicators defined by CETYS in its development plan for 2020 and those defined by CACEI and FIMPES; however, there are also a set of indicators defined by the accrediting agencies that are not explicitly stated in the CETYS development plan, and vice-versa. 
Table 7. Relationship between educational quality indicators defined by CETYS, FIMPES and CACEI

\begin{tabular}{|c|c|c|c|}
\hline Category & Indicators & FIMPES Indicators & CACEI Indicators \\
\hline \multirow{9}{*}{ 1. Students } & 1.1 Admission test scores & \multirow{9}{*}{$\begin{array}{l}\text { They relate to FIMPES } \\
\text { indicators for Students, } \\
\text { however, there are } \\
\text { indicators defined by } \\
\text { CETYS that are not } \\
\text { specifically defined as } \\
\text { such by FIMPES such } \\
\text { as institutional and } \\
\text { program learning } \\
\text { outcomes. }\end{array}$} & \multirow{9}{*}{$\begin{array}{c}\text { They relate to CACEI } \\
\text { indicators for Students, } \\
\text { however there are } \\
\text { indicators defined by } \\
\text { CETYS that are not } \\
\text { specifically defined as } \\
\text { such by CACEI such as } \\
\text { institutional and program } \\
\text { learning outcomes. }\end{array}$} \\
\hline & 1.2 Student population & & \\
\hline & 1.3 Retention & & \\
\hline & 1.4 Efficiency and attrition & & \\
\hline & 1.5 Standardized test results (EGEL). & & \\
\hline & 1.6 Institutional learning outcomes. & & \\
\hline & $\begin{array}{l}\text { 1.7 Academic program learning } \\
\text { outcomes }\end{array}$ & & \\
\hline & 1.8 Co-curriculum & & \\
\hline & 1.9 Satisfaction with regards to services & & \\
\hline \multirow{5}{*}{ 2. Faculty } & 2.1 Curricular coverage in hours & \multirow{5}{*}{$\begin{array}{l}\text { They relate directly to } \\
\text { FIMPES indicators for } \\
\text { Faculty and Research. }\end{array}$} & \multirow{5}{*}{$\begin{array}{l}\text { They relate directly to } \\
\text { CACEI indicators for } \\
\text { Faculty, Research and } \\
\text { Technological } \\
\text { Development and } \\
\text { Linkage-Extension. }\end{array}$} \\
\hline & 2.2 Doctoral studies & & \\
\hline & 2.3 Faculty performance & & \\
\hline & 2.4 Research productivity & & \\
\hline & $\begin{array}{l}2.5 \text { Research and linkage projects (via } \\
\text { the Centers of Excellence). }\end{array}$ & & \\
\hline \multirow[b]{2}{*}{ 3. Alumni } & $\begin{array}{l}\text { 3.1 Employment after one year of } \\
\text { completion of academic program }\end{array}$ & \multirow{2}{*}{$\begin{array}{l}\text { These are not directly } \\
\text { related as such to } \\
\text { FIMPES indicators }\end{array}$} & \multirow{2}{*}{$\begin{array}{l}\text { They relate to CACEI } \\
\text { indicators for } \\
\text { Linkage-Extension, a } \\
\text { category of indicators } \\
\text { where CACEI places } \\
\text { alumni follow-up. }\end{array}$} \\
\hline & $\begin{array}{l}\text { 3.2 Professional performance as } \\
\text { evaluated by employers }\end{array}$ & & \\
\hline \multirow{6}{*}{ 4. Programs } & 4.1 National program accreditation & \multirow{6}{*}{$\begin{array}{l}\text { They relate to FIMPES } \\
\text { indicators for Academic } \\
\text { Programs, however } \\
\text { there are indicators } \\
\text { defined by CETYS that } \\
\text { are not specifically } \\
\text { defined as such by } \\
\text { FIMPES, such as } \\
\text { national and } \\
\text { international } \\
\text { accreditation, as well as } \\
\text { the integration of } \\
\text { differentiating } \\
\text { elements, which are } \\
\text { particular to CETYS. }\end{array}$} & \multirow{6}{*}{$\begin{array}{l}\text { They relate to CACEI } \\
\text { indicators for Academic } \\
\text { Programs, however there } \\
\text { are indicators defined by } \\
\text { CETYS that are not } \\
\text { specifically defined as } \\
\text { such by CACEI, such as } \\
\text { national and international } \\
\text { accreditation, as well as } \\
\text { the integration of } \\
\text { differentiating elements, } \\
\text { which are particular to } \\
\text { CETYS. }\end{array}$} \\
\hline & 4.2 International program accreditation & & \\
\hline & 4.3 Program review and evaluation & & \\
\hline & $\begin{array}{l}\text { 4.4 New academic program in } \\
\text { congruence with regional development }\end{array}$ & & \\
\hline & $\begin{array}{l}\text { 4.5 Integration of differentiating } \\
\text { elements such as entrepreneurship, } \\
\text { internationalization and sustainability }\end{array}$ & & \\
\hline & $\begin{array}{l}\text { 4.6 Diversification of academic } \\
\text { offering (dual degrees, on-line } \\
\text { programs, certificates, etc.) }\end{array}$ & & \\
\hline \multirow{5}{*}{$\begin{array}{l}\text { 5. Administration } \\
\text { and Finances }\end{array}$} & 5.1 Operational results & \multirow{5}{*}{$\begin{array}{l}\text { They directly relate to } \\
\text { FIMPES indicators for } \\
\text { Planning and Financial } \\
\text { Resources. }\end{array}$} & \multirow{5}{*}{$\begin{array}{c}\text { They relate directly to } \\
\text { CACEI indicators for } \\
\text { Administration and } \\
\text { Finances. }\end{array}$} \\
\hline & 5.2 External funding sources & & \\
\hline & 5.3 Fundraising campaign & & \\
\hline & 5.4 Alumni donors & & \\
\hline & 5.5 Scholarships & & \\
\hline
\end{tabular}

\section{Unified Perspective for Categorization of Educational Quality Indicators}

Based upon the premise that it is possible to group educational quality indicators from the perspective of accreditation processes, regardless of the profile or philosophy of the accreditation agency, or if the accreditation process is at the institutional or program level, a Unified Perspective for Categorization of Educational Quality Indicators is proposed, presented in Figure 3 and described in Table 8. 


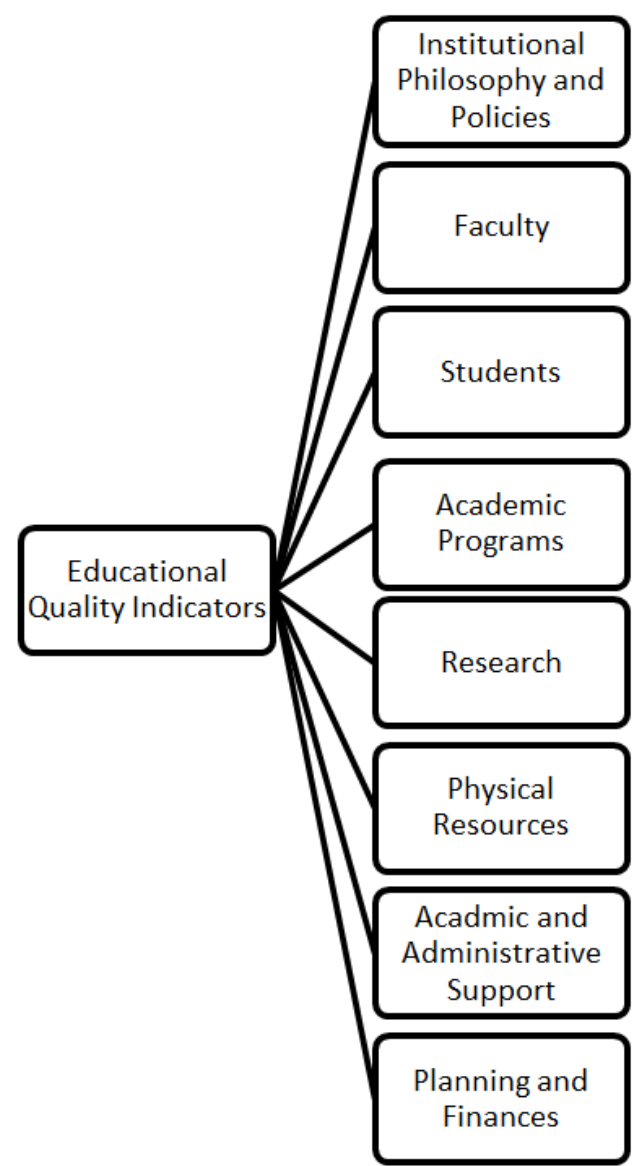

Figure 3. Unified Perspective for Categorization of Educational Quality Indicators

Table 8. Description of the categories of the Unified Perspective for Categorization of Educational Quality Indicators

\begin{tabular}{ll}
\hline Category & Description \\
\hline $\begin{array}{l}\text { Institutional } \\
\text { Philosophy and } \\
\text { Policies }\end{array}$ & $\begin{array}{l}\text { Indicators relating to the long term purpose of the institution and how to achieve it in time, the } \\
\text { validation of its existence, its educational goals and model, the social needs it responds to, the } \\
\text { definition of the course for the institution, as well as the regulatory framework and policies } \\
\text { that rule the operation of the institution. } \\
\text { Indicators relating to the profile of the faculty supporting the institution's academic activities, } \\
\text { focusing on the learning process as well as research. } \\
\text { Indicators relating to the profile and characteristics of the student population, from } \\
\text { prospective students to alumni. } \\
\text { Indicators relating to the academic offering of the institution with regards to its academic } \\
\text { programs and degrees, as well as their structure, review and evaluation. } \\
\text { Indicators relating to research activity in the institution, its primary actors, stakeholders and } \\
\text { support resources, as well as research lines, projects and initiatives. } \\
\text { Indicators relating to the physical resources the institution counts on to support its purpose as } \\
\text { it relates to the academic offering and educational model, research, as well as facilities for } \\
\text { cultural and sports activities. } \\
\text { Indicators relating to support services for the institutional community (students, faculty, } \\
\text { alumni, etc.) as well as the administrative personnel who work in these service areas. }\end{array}$ \\
Phesearch & $\begin{array}{l}\text { Indicators relating to the institution's strategic planning cycles, focused on continuous } \\
\text { improvement, as well as the financial resources that support the institution and the planning } \\
\text { and administration processes associated to these. }\end{array}$ \\
\hline $\begin{array}{l}\text { Academic and } \\
\text { Administrative }\end{array}$ & $\begin{array}{l}\text { Support } \\
\text { Planning and Finances }\end{array}$ \\
\hline
\end{tabular}




\section{Conclusions, Findings and Contributions}

Accreditation in México has evolved from having a focus primarily on capacity towards educational effectiveness, with a vision towards educational processes and their results.

From the research done on FIMPES and CACEI we found that the educational quality indicators that these agencies define at the institutional and program level are similar, regardless of the profile or philosophy of the accreditation agency, and even though institutional and program accreditation are two distinct views of the educational institution from two different perspectives, the categories of evaluation are consistent and have coinciding elements.

Aspects relating to faculty, academic programs, students, resources, planning and research are evaluated by accrediting agencies and are congruent with educational quality indicators that institutions seek regardless of accreditation. The CETYS University case study, as an institution that does planning and continuous improvement in 10 year cycles, also shows that the educational quality indicators that have been defined by the institution are congruent with those defined by FIMPES and CACEI.

Therefore, the primary finding of this research is the affinity and relationships that may be established between educational quality indicators, regardless of the type of profile of the academic institution and from the perspective of accreditation, regardless of the profile or philosophy of the accrediting agency or of the accreditation is at the institutional or program level.

Based upon this finding, relationships were established between indicators defined by FIMPES and CACEI, as well as those defined by institutions associated to FIMPES and CETYS University as a case study, where it was possible to group these relationships into categories that provide a basis for the definition of educational quality indicators from an accreditation perspective.

Therefore, the primary contribution of this research work is the Unified Perspective for Categorization of Educational Quality Indicators, which is congruent with accrediting models, as well as the educational quality elements defined by institutions of higher education as a part of their institutional planning. The structure provides a framework for the definition of activities relating to the identification, gathering and organization of information and documents relating to educational quality indicators as evidence for compliance in accreditation processes.

Further research has may be with regard to using the Unified Perspective for Categorization of Educational Quality Indicators to develop models for the identification, gathering and organization of information (documents and data) relating to educational quality indicators for compliance of accreditation requirements and to define the level of maturity of the institution with regards to the management of information regarding educational quality indicators.

\section{References}

Asociación Nacional de Universidades e Instituciones de Educación Superior ANUIES. (2014). Retrieved from www.anuies.mx

Baker, R.L. (2002). Evaluating Quality and Effectiveness: Regional Accreditation Principles and Practices. The Journal of Academic Librarianship, 28(1), 3-7. http://dx.doi.org/10.1016/S0099-1333(01)00279-8

Barragan, J. (2009). Estándares característicos de una escuela internacional: el impacto de la acreditación internacional de programas en la educación superior. Daena: International Journal of Good Conscience. 4(2), 174-187.

Brennan, L.L., \& Austin, W.W, (2003). Addressing the Need for Management Processes for Higher Education Accreditation. Innovative Higher Education, 28(1), 49-62. http://dx.doi.org/10.1023/A:1025415618658

Consejo de Acreditación de la Enseñanza de la Ingeniería CACEI (2014). Retrieved from www.cacei.org.

Consejo para la Acreditación de Programas de Educación Superior COPAES (2014). Retrieved from www.copaes.org.

Fernandez, N. (2003). Higher Education, Quality Evaluation and Accreditation in Latin America and MERCOSUR. European Journal of Education, 38(3), 253-269. http://dx.doi.org/10.1111/1467-3435.00145

Federación de Instituciones Mexicanas Particulares de Educación Superior FIMPES. Retrieved from www.fimpes.org.mx.

Harvey, L. (2004). The Power of Accreditation: Views of academics. Journal of Higher Education Policy and Management, 26(2), 207-223. http://dx.doi.org/10.1080/1360080042000218267 
Heitmann, G., \& Augusti, G. (2001). Recognition and accreditation of higher education in Europe. European Journal of Engineering Education, 26(3), 209-217. http://dx.doi.org/10.1080/0304379011005339 2

Hernandez, R., Fernandez, C., \& Baptist, P. (2010). Metodología de la investigación. (5ta. Ed). México: McGrawHill.

Pereira, J., Lutz, K., \& Hereens N. (2002). European Student Handbook on Quality Assurance in Higher Education. Retrieved from www.esib.org.

Reddy, Y.M. (2006). Global Accreditation Systems in Management Education: A Critical Analysis. South Asian Journal of Management, 15(2), 61-80.

Sánchez, M., Cantú, L., Rojas, C., Ortega, J., Valenzuela, L. (2012). Knowledge Based Model to Support Accreditation Program in Higher Education. Journal of International Management and Finance, 5(5), 99-120.

Wood, A.L. (2006). Demystifying Accreditation: Action Plans for a National or Regional Accreditation. Innovative Higher Education, 31(1), 43-62. http://dx.doi.org/10.1007/s10755-006-9008-6

Zapata, G., \& Tejeda, I. (2009). Impactos del Aseguramiento de la Calidad y Acreditación de la Educación Superior. Consideraciones y Proposiciones. Calidad en la Educación, 31,191-209. 